\title{
1 Antimicrobial peptides in human corneal tissue of fungal keratitis patients
}

2

3 Imran Mohammed, $\mathrm{PhD}^{1 \text {, a }}$, Debasmita Mohanty, $\mathrm{PhD}^{2, \text { a }}$, Dalia G. Said, $\mathrm{MD}^{1}$, Manas Ranjan Barik,

$4 \mathrm{PhD}^{3,4}$, Mamatha Reddy, $\mathrm{PhD}^{3}$, Ahmed Al-Saadi, MD ${ }^{5}$, Sujata Das, $\mathrm{MD}^{6}$, Harminder S. Dua, MD,

$5 \quad \mathrm{PhD}^{1, \mathrm{~b}, \$}$ and Ruchi Mittal MD, $\mathrm{PhD}^{2, \mathrm{~b}}$

6

7 1. Academic Ophthalmology, Division of Clinical Neuroscience, School of Medicine, University of 8 Nottingham, Nottingham, United Kingdom.

9 2. Kanupriya Dalmia Ophthalmic Pathology Laboratory, L V Prasad Eye Institute, MTC Campus, Patia, Bhubaneswar-751024, Odisha, India

3. L V Prasad Eye Institute, MTC Campus, Bhubaneswar, Odisha, India.

4. Ocular Microbiology Service, L V Prasad Eye Institute, MTC Campus, Bhubaneswar, India

5. Ophthalmology Department, Zayed Military Hospital, Abu Dhabi, United Arab Emirates

6. Cornea and Anterior Segment Service, L V Prasad Eye Institute, MTC Campus, Bhubaneswar, Odisha, India.

a. Equally contributing first authors

b. Equally contributing corresponding authors

\section{${ }^{\$}$ Correspondence:}

Harminder Singh Dua

Chair and Professor of Ophthalmology

University of Nottingham

B Floor, Eye \& ENT Building

Queens Medical Centre

Derby Road, Nottingham NG7 2UH

United Kingdom

E-mail: Harminder.Dua@nottingham.ac.uk and profdua@gmail.com

Tel: +44-1159709796 and +44-1159249924 ext. 63757 


\section{$39 \quad$ Precis}

40 HBD-1 and -2 were consistently expressed in fungal keratitis samples. While HBD-3, -9, S100A7,

41 and LL-37 showed variable expression pattern. The results indicate the therapeutic potential of

42 recombinant or linear AMPs against fungal pathogens.

43

44

45

46

47

48

49

50

51

52

53

54

55

56

57

58

59

60

61

62

63 
Background: Fungal keratitis (FK) is the leading cause of unilateral blindness in the developing world. Antimicrobial peptides (AMPs) have been shown to play an important role on human ocular surface (OS) during bacterial, viral, and protozoan infections. Here, our aim was to profile a spectrum of AMPs in corneal tissue from FK patients with active infection and after healing.

Methods: OS samples were collected from patients at presentation by impression cytology and scraping. Corneal button specimens were collected from patients undergoing therapeutic penetrating keratoplasty for management of severe FK or healed keratitis. Gene expression of human betadefensin (HBD)-1, -2, -3 and -9, S100A7, and LL-37 was determined by quantitative real-time polymerase chain reaction (qPCR).

76

Results: Messenger RNA expression (mRNA) for all AMPs was shown to be significantly upregulated in FK samples. Levels of HBD-1 and -2 mRNA were found to be elevated in 18/20 FK samples. Whereas mRNA for HBD-3 and S100A7 was upregulated in 11/20 and HBD9 was increased in 15/20 FK samples. LL-37 mRNA showed moderate upregulation in 7/20 FK samples compared to controls. In healed scar samples, mRNA of all AMPs was found to be low and matching the levels in controls.

84 Conclusion: AMP expression is a consistent feature of $\mathrm{FK}_{2}$ but not all AMPs are equally expressed.

85 HBD-1 and -2 are most consistently expressed and LL-37 the least, suggesting some specificity of 86 AMP expression related to FK. This information will be useful in developing strategies $\underline{\text { The outcomes }}$

87 will form the basis to use HBDs sequence as a template for designing FK-specific peptide therapeutics for use of AMPs in treating FK. 


\section{INTRODUCTION}

94 Fungal keratitis (FK) is the commonest cause of corneal blindness in developing world. The prevalence of FK has been linked to geographical climate ${ }^{1}$. In India, it was estimated that up to $35 \%$ of patients that present with infective keratitis were culture positive for mycotic organisms ${ }^{23}$. The principal risk factor for FK in more than $70 \%$ of these cases was reported to be vegetative ocular injury $^{3}$. Increasing reports of FK cases from countries with temperate conditions have added to the infection-related incidence of blindness globally ${ }^{4-6}$. In developed countries, incidence of FK cases is also increasing and mainly associated with contact-lens use and ocular trauma ${ }^{7}$. In the United Kingdom, FK incidence increased from 4.5 cases per year (between 1994 to 2006) to 14 cases per year (between 2007 to 2014$)^{5}$. In the midwestern region of the United States, $16 \%$ cases of infective keratitis (between 1999 to 2013) were identified as FK with poor healing and major complications ${ }^{8}$. The socio-economic impact of this disease has been significantly high because it predominantly affects individuals in working age group ${ }^{9-11}$. Clinical features of FK often overlap with bacterial keratitis and frequently these are difficult to diagnose ${ }^{12}$. Poor penetration and lack of effective antifungal agents has further compounded the problem of $\mathrm{FK}^{13-15}$. Therefore, to seek alternative therapies, current research in this field has been mainly focused on understanding of mechanisms by which host immunity responds to fungi and yeast.

Antimicrobial peptides (AMPs) are naturally occurring host defence proteins with broad-spectrum antimicrobial activity against bacteria, fungi and viruses ${ }^{16-18}$. They play an important role in innate

113 immunity and are known to be expressed at epithelial surfaces of the human body. We were the first 114 group to provide evidence for the presence of AMPs at the ocular surface ${ }^{19}$ and profiled the range of 115 AMPs (human beta-defensin (HBD)-1 to 3, HBD-9 and cathelicidin (LL-37)) at the human ocular surface and their expression in corneal infections ${ }^{20-22}$. We also elucidated the signaling mechanisms involved in RNase-7 and HBD-9 secretion from human corneal epithelial cells ${ }^{23} 24$. 
119 Antifungal activity of AMPs (such as defensins and cathelicidin) is well known ${ }^{25-27}$ through animal

120 studies, but the profile of human AMPs at the ocular surface in response to fungal infections has not

121 been elucidated. In this study, we profiled the gene expression of well-characterised human AMPs in

122 corneal specimens during active phase of infection and after healing.

123

124

125

MATERIALS AND METHODS

126 Research was conducted in accordance with the tenets of the Declaration of Helsinki. Study was

127 approved by the Institutional Review Board of Hyderabad Eye Research Foundation (Ethics code:

128 2016-13-CD-13), L.V. Prasad Eye Institute (LVPEI), Bhubaneswar, India. Informed consent was

129 obtained from all patients prior to collection of samples, which included scrapes/ impression cytology

130 from patients with active fungal keratitis, corneal buttons (part of) from patients that were subjected

131 to therapeutic penetrating keratoplasty (tPK) for fungal keratitis not responding to medical

132 management and corneal tissue from patients with non-inflammatory corneal scar that underwent

133 optical penetrating keratoplasty (controls).

134

135 Study design:

136 A prospective consecutive case series of patients with fungal keratitis

$137 \quad$ Inclusion criteria

138

- Patients diagnosed clinically as suffering from FK and confirmed by standard microbiology and/or histopathology techniques.

140 - Patients with active FK who had received no treatment or were unresponsive to treatment.

- Patients of 18 years of age or older.

142 - Patients able to give informed consent.

143

$144 \quad$ Exclusion criteria

145 - Patients with mixed fungal and bacterial keratitis 
151 Sample collection:

152 Corneal scrapes were collected using standard techniques with sterile Bard Parker blade number $15^{28}$.

- Patients on topical or systemic steroid treatment

- Patients on immunosuppressive treatment or known to be immunosuppressed

- Patients presenting with non-infectious causes of ocular inflammation

- Patients with viral keratitis

Impression cytology (IC) was performed to collect superficial layers of corneal epithelium using cellulose acetate ester discs, as previously reported ${ }^{20}$. Part of corneal button (CB) from patients undergoing therapeutic or optical PK was collected in $600 \mu \mathrm{L}$ RNAlater solution (Qiagen, Germany) on ice and then transferred to buffer RLT prior to storage at $-80^{\circ} \mathrm{C}$.

\section{Total RNA isolation and Reverse transcription:}

Corneal tissue in RLT buffer was homogenized using a tissue ruptor (Qiagen, Germany) for 60 seconds on ice. Total RNA was isolated from CB, IC samples, and corneal scrapes using RNeasy Mini Kit (catalog No. 74104; Qiagen, Germany) according to manufacturers' instructions, including the optional DNase step. Isolated RNA was quantitated using Biospectrophotometer (Eppendorf, Germany). 200ng total RNA was reverse transcribed to complementary deoxyribonucleic acid (cDNA) using Eurogentec Reverse Transcription Core Kit (RT-RTCK-03, Eurogentec, Belgium) as per manufacturers' instructions. No RT-enzyme control samples were also prepared.

\section{Quantitative real-time polymerase chain reaction (qPCR):}

Quantitative PCR was conducted for selected AMPs (Table 1) using Taqman probe chemistry. Taqman assays specific to AMPs, hypoxanthine-guanine phosphoribosyltransferase [HPRT] and appropriate controls were run in duplicate in a 96-well plate in the Mx3005p real-time PCR instrument (Agilent technologies, Milton Keynes, UK). Briefly, template cDNA was initially diluted to 1 in 5 using nuclease-free water. A $20 \mu \mathrm{L}$ reaction mix was prepared for each well as per 
174 reaction mixture comprised of $10 \mu \mathrm{L}$ of $2 \mathrm{x}$ mastermix, $1 \mu \mathrm{L}$ of $20 \mathrm{x}$ taqman assay, $5 \mu \mathrm{L}$ of diluted

$175 \mathrm{cDNA}$ and $4 \mu \mathrm{L}$ of nuclease-free water. All probes used in this study were template specific. However,

176 to rule out any genomic amplification, appropriate no-RT controls were also included against each

177 gene probe. $\mathrm{C}_{\mathrm{T}}$ values were acquired using MxPro Software version 5.0 and further analysed by delta178 delta $\mathrm{C}_{\mathrm{T}}$ comparative method ${ }^{29}$.

\section{Statistical analysis:}

The qPCR data was subjected to statistical analysis using Prism version 8.1 software (GraphPad performed unpaired Welch's unequal variances $t$-test for control versus active and active versus healed groups.

\section{RESULTS}

As shown in table 2, a total 26 samples were collected. These included a part of CB $(n=17)$, scrapings $(n=5)$ and IC $(n=4)$. Of CB specimens, 3 were grouped as 'controls' (patients' that required optical PK for management of non-inflammatory corneal scar); 11 were grouped as 'active FK' (patients' with severe FK that required tPK) and 3 were grouped as 'healed' keratitis (patients' that required PK post-medical management for FK). Table 2 mentions the day of collection of corneal button samples

193 (Column no.8). CB tissue of active FK was collected between day 1 to 30 from the day of presentation and those from the healed group between 6-12 months from the day of presentation. Scraping and IC samples (5+4) were also included under the group of 'active FK' and were collected between day 0 to 3 from the day of presentation, before commencement of antifungal therapy. In total, we studied $n=3$ in controls; $n=20$ in active FK and $n=3$ in healed group. As shown in table 2,

198 final diagnosis was based on positive growth of fungi in cultures from corneal scrapings and/or on 199 histopathology evaluation. Of $n=23$ cases of fungal keratitis, 3 samples showed no growth on culture, 
200

201

202

203

204

205

206

207

208

209

210

211

212

213

214

215

216

217

218

219

220

221

222

223

224

225

however, they were later confirmed as fungal by aetiology on histological evaluation. In addition, 2/23 patients presented with a perforation or an impending perforation were not scraped but later confirmed as FK, on histopathology. A range of fungi were identified but fusarium species was the most common (Table 2).

\section{Variable expression of AMPs in active FK and healed samples}

HBD-1, -2, and -9 and LL-37 were shown to be constitutively expressed in all control samples, whereas mRNAs for HBD-3 and S100A7 were expressed at a very low level in controls. As shown in figure 1, all AMPs were significantly increased during active FK. Notably, in healed samples, their mRNA expression was found to be at a similar level to those in controls. Levels of mRNA expression is denoted as mean \pm standard deviation.

HBD-1 and -2 mRNA were significantly increased in 18/20 active FK samples. HBD-1 was upregulated by $12.03 \pm 9.06$ fold $(p<0.0001)$ and HBD- 2 was elevated by $254.7 \pm 335.82$ fold $(p=0.003)$ in FK compared to controls. However, in healed samples, these levels were significantly reduced with HBD-1 at $2.19 \pm 1.72$ fold $(p=0.0003)$ and HBD- 2 at $0.23 \pm 0.28$ fold $(p=0.003)$ compared to active FK.

The level of HBD-3 and S100A7 mRNAs were elevated in 11/20 FK samples, whereas HBD9 mRNA was upregulated (> 2-fold) in 15/20 FK samples. HBD-3 was increased by $5.54 \pm 8.28$ fold $(p=0.007)$ and HBD-9 was elevated by $31.83 \pm 51.15$ fold $(p=0.018)$ in FK. Similar to other defensins, HBD-3 and HBD-9 also showed baseline expression in healed samples with levels at $0.01 \pm 0.02$ fold $(p=0.007)$ and $0.51 \pm 0.40$ fold $(p=0.013)$, respectively. S100A7 mRNA expression was shown to be increased by $61.89 \pm 95.73$ fold $(p=0.009)$ in FK samples compared to controls. Whereas in healed samples, mRNA levels for S100A7 were reduced to $0.19 \pm 0.34$ fold $(p=0.009)$ compared to FK. 

\pm 1.01 fold; not significant) matching the mRNA levels in controls.

\section{DISCUSSION}

230 AMPs have attracted special attention as potential therapy for microbial infections due to their unique mode of action compared to available antimicrobial therapies ${ }^{30}$. In the last two decades, we and others have extensively demonstrated an essential role of human AMPs in microbial keratitis ${ }^{17}$ 19-23 $^{1-33}$. In corneal epithelial cells, expression of HBD-2, HBD-3 and LL-37 were shown to be significantly elevated in response to infection with Fusarium solani ${ }^{34}$ and Candida albicans ${ }^{35}$, respectively. Elevated levels of cytokines and other innate immune receptors was previously demonstrated in human corneal specimen from patients with Aspergillus flavus and Fusarium solani infection ${ }^{36}$. Moreover, increased susceptibility to corneal infections by Aspergillus fumigatus, Fusarium solani and Candida albicans was previously demonstrated in mice deficient in cathelin-related antimicrobial peptide (CRAMP) and murine $\beta$-defensins (mBD-1 to -4$)^{37} 38$.

241 In this study, we demonstrated an increased pattern of AMPs (HBD-1 to -3, HBD-9, S100A7 and LL37) expression in corneal specimen during active infection. Notably, in healed specimen, mRNA of all AMPs was found to be at a basal level. A similar phenomenon has been noted in our previous demonstration of HBD-3 and HBD-9 mRNA levels in OS specimen collected during active bacterial keratitis and following complete healing ${ }^{31}$. Moreover, in an animal model of Candida albicans keratitis, CRAMP and $\beta$-defensins (mBD-1 and -2) have demonstrated a variable expression at the onset of disease but returned to their normal level upon healing at day 7 post-infection ${ }^{38}$. In Fusarium solani keratitis mouse model, mBD-3, mBD-4, mBD-14 and CRAMP were shown to be significantly increased by day 3 post-infection, which then started to decrease with reduction in disease severity reaching to baseline upon healing ${ }^{37}$. From above studies, it could be inferred that rapid normalisation of AMPs expression following healing occurs and is likely to be of importance considering the fact that high levels of AMPs could elicit toxic responses on ocular surface. 
254 Previously we have demonstrated a significant downregulation of HBD9 expression in specimen from 255 patients with bacterial keratitis, acanthamoeba keratitis, viral keratitis and dry-eye disease ${ }^{20}$.

256 Interestingly, in current study, we have noted an elevated pattern of HBD9 expression in active FK

257 samples. This unique response of HBD9 during fungal infection suggest a potential anti-fungal

258 function of this AMP. We have generated the recombinant protein of HBD9 using E. coli expression

259 system and demonstrated that both recombinant HBD9 protein and its full-length synthetic linear

260 peptide were unstable, which was attributed to its proline rich C-terminus. Failure to keep the protein

261 or its linear peptide in solution has thus far prevented us to test the antimicrobial efficacy of HBD9

262 against disease-causing pathogens (unpublished observations).

263

264 S100A7 was first isolated from skin of Psoriasis patients hence it is also known as Psoriasin ${ }^{39}$.

265 S100A7 has been shown to express constitutively in different regions of anterior segment of the eye ${ }^{40}$.

266 Interestingly, cysteine-reduced form of S100A7 protein has been previously shown to exhibit potent

267 antifungal activity against dermatophytes and filamentous fungi ${ }^{41}$. Whereas both native and reduced

268 forms of S100A7 showed activity against the yeast, C. albicans ${ }^{41}$. A previous study has demonstrated

269 the increased levels of S100A7 in vaginal biopsies from patients with C. albicans vulvovaginitis ${ }^{42}$.

270 Similar increased levels of S100A7 were also noted in this study. Further research using gene

271 knockout experiments would highlight the importance of S100A7 in host defense to fungal infections

272 at the ocular surface.

273

274 Although FK is slowly progressive compared to bacterial keratitis, the rate of corneal perforation has 275 been reported to be high in FK cases $^{43}$. AMPs are potent chemo attractants and capable of eliciting 276 adaptive immunity ${ }^{30}$. Thus, in addition to direct killing of microbes, increased level of AMPs during 277 FK could potentially increase neutrophil infiltration, which might contribute towards tissue damage, melting, and scarring. A recent report has demonstrated that deficiency of CRAMP and mBD-3 and -4

279 increased the susceptibility to $F$. solani keratitis and led to excessive infiltration of neutrophils which was attributed to high levels of KC (a neutrophil chemokine) in corneal tissue ${ }^{37}$. Similarly, in $C$. 
albicans keratitis model, deletion of CRAMP was also shown to increase yeast burden, neutrophil recruitment and levels of IL-1 $\beta$ and MIP- $2^{44}$. In stark contrast to keratitis model, severity of $C$. albicans infection in oral mucosa in mBD-1 knockout mice have been associated with low neutrophil recruitment and reduced levels of IL- $1 \beta, \mathrm{KC}$, IL-17A and IL-17F $\mathrm{F}^{45}$. In mice cornea, the specific function of neutrophil derived calprotectin (S100A8/A9) in clearance of A. fumigatus has been demonstrated. Unlike cationic AMPs, calprotectin was shown to exhibit antifungal activity via chelation of zinc and manganese which retards A. fumigatus growth ${ }^{46}$.

Our results corroborate previous studies on AMP regulation during fungal infection in animals. This further implicates a pivotal role for AMPs in OS defense against fungal pathogens. However, their diverse function in modulation of neutrophil infiltration and inflammation in cornea and other mucosal sites during infection still remains unclear. Though this is the first study on AMPs in human FK further studies are highly warranted to understand the mechanisms of immune activation of AMPs during FK. The limitation of this study was that it only involved assessment of gene expression of AMPs in active and healed groups. A follow-up study addressing the cellular source of these AMPs in active FK samples will further enhance the understanding of function of key AMPs towards fungi/yeast.

\section{ACKNOWLEDGEMENT}

Funding supported by the Fight for Sight small grant award (Ref: 5007/08) to HSD and IM.

301

Authors wish to express their gratitude to Dr. Srikant Kumar Sahu, Dr. Smruti Rekha Priyadarshini, Dr. Sanchita Mitra and Aparajita Mallick for their clinical, laboratory, and technical support.

IM: None 
DSG: None

MRB: None

MR: None

AAS: None

SD: None

HSD: Honoraria and Travel expenses from Dompe, Croma, Santen, Allergan, Thea. Shares in

NuVision Biotherapies and Glaxo Smithkline.

RM: None

\section{REFERENCES}

320

1. Shah A, Sachdev A, Coggon D, et al. Geographic variations in microbial keratitis: an analysis of the peer-reviewed literature. Br J Ophthalmol 2011;95(6):762-7. doi: 10.1136/bjo.2009.169607

2. Bharathi MJ, Ramakrishnan R, Meenakshi R, et al. Microbial keratitis in South India: influence of risk factors, climate, and geographical variation. Ophthalmic Epidemiol 2007;14(2):61-9. doi: 10.1080/09286580601001347

3. Lalitha P, Prajna NV, Manoharan G, et al. Trends in bacterial and fungal keratitis in South India, 2002-2012. Br J Ophthalmol 2015;99(2):192-4. doi: 10.1136/bjophthalmol-2014-305000 [published Online First: 2014/08/22]

4. Gower EW, Keay LJ, Oechsler RA, et al. Trends in fungal keratitis in the United States, 2001 to 2007. Ophthalmology 2010;117(12):2263-7. doi: 10.1016/j.ophtha.2010.03.048 [published Online First: 2010/07/02]

5. Ong HS, Fung SS, Macleod D, et al. Altered Patterns of Fungal Keratitis at a London Ophthalmic Referral Hospital: An Eight-Year Retrospective Observational Study. Am J Ophthalmol 2016;168:227-36. doi: 10.1016/j.ajo.2016.05.021

6. Keay LJ, Gower EW, Iovieno A, et al. Clinical and microbiological characteristics of fungal keratitis in the United States, 2001-2007: a multicenter study. Ophthalmology 2011;118(5):920-6. doi: 10.1016/j.ophtha.2010.09.011 [published Online First: 2011/02/08]

7. Estopinal CB, Ewald MD. Geographic Disparities in the Etiology of Bacterial and Fungal Keratitis in the United States of America. Semin Ophthalmol 2016;31(4):345-52. doi: 10.3109/08820538.2016.1154173 [published Online First: 2016/04/22]

8. Hsu HY, Ernst B, Schmidt EJ, et al. Laboratory Results, Epidemiologic Features, and Outcome Analyses of Microbial Keratitis: A 15-Year Review From St. Louis. Am J Ophthalmol 2019;198:54-62. doi: 10.1016/j.ajo.2018.09.032 [published Online First: 2018/10/12]

9. Acharya Y, Acharya B, Karki P. Fungal keratitis: study of increasing trend and common determinants. Nepal J Epidemiol 2017;7(2):685-93. doi: 10.3126/nje.v7i2.17975 [published Online First: 2017/11/29] 
10. Collier SA, Gronostaj MP, MacGurn AK, et al. Estimated burden of keratitis--United States, 2010. MMWR Morb Mortal Wkly Rep 2014;63(45):1027-30. [published Online First: 2014/11/14]

11. Gupta N, Tandon R, Gupta SK, et al. Burden of corneal blindness in India. Indian J Community Med 2013;38(4):198-206. doi: 10.4103/0970-0218.120153 [published Online First: 2013/12/05]

12. Said DG, Otri M, Miri A, et al. The challenge of fungal keratitis. Br J Ophthalmol 2011;95(12):1623-4. doi: 10.1136/bjophthalmol-2011-301148 [published Online First: 2011/11/19]

13. Lakhani P, Patil A, Majumdar S. Challenges in the Polyene- and Azole-Based Pharmacotherapy of Ocular Fungal Infections. J Ocul Pharmacol Ther 2019;35(1):6-22. doi: 10.1089/jop.2018.0089 [published Online First: 2018/11/28]

14. Austin A, Lietman T, Rose-Nussbaumer J. Update on the Management of Infectious Keratitis. Ophthalmology 2017;124(11):1678-89. doi: 10.1016/j.ophtha.2017.05.012 [published Online First: 2017/09/25]

15. Prajna NV, Krishnan T, Rajaraman R, et al. Effect of Oral Voriconazole on Fungal Keratitis in the Mycotic Ulcer Treatment Trial II (MUTT II): A Randomized Clinical Trial. JAMA Ophthalmol 2016;134(12):1365-72. doi: 10.1001/jamaophthalmol.2016.4096 [published Online First: 2016/10/28]

16. Mansour SC, Pena OM, Hancock RE. Host defense peptides: front-line immunomodulators. Trends Immunol 2014;35(9):443-50. doi: 10.1016/j.it.2014.07.004

17. Mohammed I, Said DG, Dua HS. Human antimicrobial peptides in ocular surface defense. Prog Retin Eye Res 2017;61:1-22. doi: 10.1016/j.preteyeres.2017.03.004 [published Online First: 2017/06/08]

18. Kolar SS, McDermott AM. Role of host-defence peptides in eye diseases. Cell Mol Life Sci 2011;68(13):2201-13. doi: 10.1007/s00018-011-0713-7 [published Online First: 2011/05/18]

19. Haynes RJ, Tighe PJ, Dua HS. Innate defence of the eye by antimicrobial defensin peptides. Lancet 1998;352(9126):451-2. doi: S0140673698240323 [pii] [published Online First: 1998/08/26]

20. Abedin A, Mohammed I, Hopkinson A, et al. A novel antimicrobial peptide on the ocular surface shows decreased expression in inflammation and infection. Invest Ophthalmol Vis Sci 2008;49(1):28-33. doi: 10.1167/iovs.07-0645

21. McIntosh RS, Cade JE, Al-Abed M, et al. The spectrum of antimicrobial peptide expression at the ocular surface. Invest Ophthalmol Vis Sci 2005;46(4):1379-85. doi: 10.1167/iovs.04-0607

22. Mohammed I, Suleman H, Otri AM, et al. Localization and gene expression of human betadefensin 9 at the human ocular surface epithelium. Invest Ophthalmol Vis Sci 2010;51(9):4677-82. doi: 10.1167/iovs.10-5334 iovs.10-5334 [pii] [published Online First: 2010/04/09]

23. Mohammed I, Yeung A, Abedin A, et al. Signalling pathways involved in ribonuclease-7 expression. Cell Mol Life Sci 2011;68(11):1941-52. doi: 10.1007/s00018-010-0540-2

24. Dua HS, Otri AM, Hopkinson A, et al. In vitro studies on the antimicrobial peptide human betadefensin 9 (HBD9): signalling pathways and pathogen-related response (an American Ophthalmological Society thesis). Trans Am Ophthalmol Soc 2014;112:50-73. [published Online First: 2015/02/04]

25. Vylkova S, Nayyar N, Li W, et al. Human beta-defensins kill Candida albicans in an energydependent and salt-sensitive manner without causing membrane disruption. Antimicrob Agents Chemother 2007;51(1):154-61. doi: 10.1128/AAC.00478-06 [published Online First: 2006/11/01]

26. den Hertog AL, van Marle J, van Veen HA, et al. Candidacidal effects of two antimicrobial peptides: histatin 5 causes small membrane defects, but LL-37 causes massive disruption of the cell membrane. Biochem J 2005;388(Pt 2):689-95. doi: 10.1042/BJ20042099 [published Online First: 2005/02/15]

27. Lopez-Garcia B, Lee PH, Yamasaki K, et al. Anti-fungal activity of cathelicidins and their potential role in Candida albicans skin infection. J Invest Dermatol 2005;125(1):108-15. doi: 10.1111/j.0022-202X.2005.23713.x [published Online First: 2005/06/29] 
28. Jones D, Liesegang, TJ, Robinson, NM Laboratory Diagnosis of Ocular Infections. Washington, DC: American Society for Microbiology 1981.

29. Livak KJ, Schmittgen TD. Analysis of relative gene expression data using real-time quantitative PCR and the 2(-Delta Delta C(T)) Method. Methods 2001;25(4):402-8. doi: 10.1006/meth.2001.1262 [published Online First: 2002/02/16]

30. Hancock RE, Sahl HG. Antimicrobial and host-defense peptides as new anti-infective therapeutic strategies. Nat Biotechnol 2006;24(12):1551-7. doi: 10.1038/nbt1267 [published Online First: 2006/12/13]

31. Otri AM, Mohammed I, Al-Aqaba MA, et al. Variable expression of human Beta defensins 3 and 9 at the human ocular surface in infectious keratitis. Invest Ophthalmol Vis Sci 2012;53(2):757-61. doi: 10.1167/iovs.11-8467 [published Online First: 2012/01/11]

32. Mohammed I, Abedin A, Tsintzas K, et al. Increased expression of hepcidin and toll-like receptors 8 and 10 in viral keratitis. Cornea 2011;30(8):899-904. doi: 10.1097/ICO.0b013e31820126e5 [published Online First: 2011/04/19]

33. Otri AM, Mohammed I, Abedin A, et al. Antimicrobial peptides expression by ocular surface cells in response to Acanthamoeba castellanii: an in vitro study. Br J Ophthalmol 2010;94(11):1523-7. doi: 10.1136/bjo.2009.178236 [published Online First: 2010/08/04]

34. Kolar SS, Baidouri H, McDermott AM. Role of Pattern Recognition Receptors in the Modulation of Antimicrobial Peptide Expression in the Corneal Epithelial Innate Response to F. solani. Invest Ophthalmol Vis Sci 2017;58(5):2463-72. doi: 10.1167/iovs.16-20658 [published Online First: 2017/05/02]

35. Hua X, Yuan X, Tang X, et al. Human corneal epithelial cells produce antimicrobial peptides LL37 and beta-defensins in response to heat-killed Candida albicans. Ophthalmic Res 2014;51(4):179-86. doi: 10.1159/000357977 [published Online First: 2014/03/26]

36. Karthikeyan RS, Leal SM, Jr., Prajna NV, et al. Expression of innate and adaptive immune mediators in human corneal tissue infected with Aspergillus or fusarium. J Infect Dis 2011;204(6):942-50. doi: 10.1093/infdis/jir426 [published Online First: 2011/08/11]

37. Kolar SS, Baidouri H, Hanlon S, et al. Protective role of murine beta-defensins 3 and 4 and cathelin-related antimicrobial peptide in Fusarium solani keratitis. Infect Immun 2013;81(8):2669-77. doi: 10.1128/IAI.00179-13 [published Online First: 2013/05/15]

38. Yuan X, Hua X, Wilhelmus KR. The corneal expression of antimicrobial peptides during experimental fungal keratitis. Curr Eye Res 2010;35(10):872-9. doi: 10.3109/02713683.2010.495812 [published Online First: 2010/09/23]

39. Madsen P, Rasmussen HH, Leffers H, et al. Molecular cloning, occurrence, and expression of a novel partially secreted protein "psoriasin" that is highly up-regulated in psoriatic skin. $J$ Invest Dermatol 1991;97(4):701-12. [published Online First: 1991/10/01]

40. Garreis F, Gottschalt M, Schlorf T, et al. Expression and regulation of antimicrobial peptide psoriasin (S100A7) at the ocular surface and in the lacrimal apparatus. Invest Ophthalmol Vis Sci 2011;52(7):4914-22. doi: 10.1167/iovs.10-6598 [published Online First: 2011/05/10]

41. Hein KZ, Takahashi H, Tsumori T, et al. Disulphide-reduced psoriasin is a human apoptosisinducing broad-spectrum fungicide. Proc Natl Acad Sci U S A 2015;112(42):13039-44. doi: 10.1073/pnas.1511197112 [published Online First: 2015/10/07]

42. Brauner A, Alvendal C, Chromek M, et al. Psoriasin, a novel anti-Candida albicans adhesin. $J$ Mol Med (Berl) 2018;96(6):537-45. doi: 10.1007/s00109-018-1637-6 [published Online First: 2018/05/08]

43. Prajna NV, Krishnan T, Rajaraman R, et al. Predictors of Corneal Perforation or Need for Therapeutic Keratoplasty in Severe Fungal Keratitis: A Secondary Analysis of the Mycotic Ulcer Treatment Trial II. JAMA Ophthalmol 2017;135(9):987-91. doi: 10.1001/jamaophthalmol.2017.2914 [published Online First: 2017/08/18]

44. Gao N, Kumar A, Guo H, et al. Topical flagellin-mediated innate defense against Candida albicans keratitis. Invest Ophthalmol Vis Sci 2011;52(6):3074-82. doi: 10.1167/iovs.10-5928 [published Online First: 2011/02/12]

45. Tomalka J, Azodi E, Narra HP, et al. beta-Defensin 1 plays a role in acute mucosal defense against Candida albicans. J Immunol 2015;194(4):1788-95. doi: 10.4049/jimmunol.1203239 [published Online First: 2015/01/18] 
458

459

460

461

462

463

464
46. Clark HL, Jhingran A, Sun Y, et al. Zinc and Manganese Chelation by Neutrophil S100A8/A9

(Calprotectin) Limits Extracellular Aspergillus fumigatus Hyphal Growth and Corneal Infection. J Immunol 2016;196(1):336-44. doi: 10.4049/jimmunol.1502037 [published Online First: 2015/11/20] 
467 Figure 1. Gene expression of antimicrobial peptides in corneal tissue from patients with fungal

468 keratitis. Relative fold change of A) HBD1, B) HBD2, C) HBD3, D) HBD9, E) S100A7 and F) LL-

46937 in control, active FK and healed groups. Data points represent individual patients in each group.

470 Student's t-test with Welch's correction was performed to compare control vs active FK and active

471 FK vs healed with $p \leq 0.05$ denotes statistical significance.

472

473 
474

475

476

477

478

479

\begin{tabular}{c|c}
\hline Gene name & Assay ID \\
\hline DEFB1 $(H B D-1)$ & Hs00608345_m1 \\
DEFB4 $(H B D-2)$ & Hs00823638_m1 \\
DEFB103(HBD-3) & Hs00218678_m1 \\
DEFB109 $(H B D-9)$ & Hs002760065_g1 \\
S100A7 & Hs00961622_m1 \\
CAMP $(L L-37)$ & Hs00189038_m1 \\
$H P R T 1$ & 4325801
\end{tabular}

480

481

482

483

484 
Table 2. Clinical diagnosis and laboratory results

\begin{tabular}{|l|l|l|l|l|l|l|l|l|l|}
\hline No. & $\begin{array}{l}\text { Age } \\
\text { /Sex }\end{array}$ & $\begin{array}{l}\text { Clinical } \\
\text { diagnosis }\end{array}$ & $\begin{array}{l}\text { Size } \\
\text { of } \\
\text { inf.(mm) }\end{array}$ & $\begin{array}{l}\text { Scr- } \\
\text { C/S }\end{array}$ & $\begin{array}{l}\text { Sam } \\
\text { ple } \\
\text { used }\end{array}$ & $\begin{array}{l}\text { Outcome } \\
\text { Keratopl } \\
\text { asty }\end{array}$ & $\begin{array}{l}\text { Pres } \\
\text { to } \\
\text { Ker }\end{array}$ & $\begin{array}{l}\text { Histopathology } \\
\text { findings }\end{array}$ & $\begin{array}{l}\text { CB- } \\
\text { C/S }\end{array}$ \\
\hline 1. & $\begin{array}{l}36 \\
\text { /M }\end{array}$ & $\begin{array}{l}\text { Corneal } \\
\text { scar }\end{array}$ & NA & NA & CB & NA/Y & $11 \mathrm{~m}$ & $\begin{array}{l}\text { Vascularised } \\
\text { corneal scar }\end{array}$ & NA \\
\hline 2. & $\begin{array}{l}38 \\
/ F\end{array}$ & $\begin{array}{l}\text { Corneal } \\
\text { scar, post } \\
\text { trauma }\end{array}$ & NA & NA & CB & NA/Y & $\begin{array}{l}5 \\
\text { yrs }\end{array}$ & $\begin{array}{l}\text { Non } \\
\text { inflammatory } \\
\text { corneal scar }\end{array}$ & NA \\
\hline 3. & $\begin{array}{l}19 \\
\text { /M }\end{array}$ & $\begin{array}{l}\text { Corneal } \\
\text { scar since } \\
\text { childhood }\end{array}$ & NA & NA & CB & NA/Y & $6 \mathrm{~m}$ & $\begin{array}{l}\text { Non } \\
\text { inflammatory } \\
\text { corneal scar }\end{array}$ & NA \\
\hline
\end{tabular}

\begin{tabular}{|c|c|c|c|c|c|c|c|c|c|}
\hline 4. & $\begin{array}{l}86 \\
/ \mathrm{M}\end{array}$ & $\begin{array}{l}\text { Microbial } \\
\text { Keratitis }\end{array}$ & $3.5 \times 2.5$ & $\begin{array}{l}\text { unid. } \\
\text { hyaline } \\
\text { fungus }\end{array}$ & $\begin{array}{l}\text { Scra } \\
\text { pe }\end{array}$ & $\begin{array}{l}\text { Resolved } \\
\text { keratitis } \\
\text { /ND }\end{array}$ & NA & NA & NA \\
\hline 5. & $\begin{array}{l}86 \\
/ \mathrm{M}\end{array}$ & $\begin{array}{l}\text { Microbial } \\
\text { Keratitis }\end{array}$ & $3.5 \times 2.5$ & $\begin{array}{l}\text { unid. } \\
\text { hyaline } \\
\text { fungus }\end{array}$ & $\operatorname{Imp}$ & $\begin{array}{l}\text { Resolved } \\
\text { keratitis/ } \\
\text { ND }\end{array}$ & NA & NA & NA \\
\hline 6. & $\begin{array}{l}30 \\
/ \mathrm{F}\end{array}$ & $\begin{array}{l}\text { Corneal } \\
\text { ulcer }\end{array}$ & TCI & $\begin{array}{l}\text { Aspergillus } \\
\text { spp. }\end{array}$ & $\begin{array}{l}\text { Scra } \\
\text { pe }\end{array}$ & $\begin{array}{l}\text { Failed to } \\
\text { resolve/ } \\
\mathrm{Y}\end{array}$ & $30 d$ & $\begin{array}{l}\text { Fungal corneal } \\
\text { ulcer }\end{array}$ & NG \\
\hline 7. & $\begin{array}{l}30 \\
/ F\end{array}$ & $\begin{array}{l}\text { Corneal } \\
\text { ulcer }\end{array}$ & TCI & $\begin{array}{l}\text { Aspergillus } \\
\text { spp. }\end{array}$ & $\operatorname{Imp}$ & $\begin{array}{l}\text { Failed to } \\
\text { resolve/ } \\
\text { Y }\end{array}$ & $30 d$ & $\begin{array}{l}\text { Fungal corneal } \\
\text { ulcer }\end{array}$ & NG \\
\hline 8. & $\begin{array}{l}22 \\
/ F\end{array}$ & $\begin{array}{l}\text { Corneal } \\
\text { ulcer }\end{array}$ & $2 \times 1.5$ & NG & $\begin{array}{l}\text { Scra } \\
\text { pe }\end{array}$ & $\begin{array}{l}\text { Partially } \\
\text { resolved } \\
\text { /Y }\end{array}$ & $30 d$ & $\begin{array}{l}\text { Fungal keratitis } \\
\text { with yeast like } \\
\text { spores }\end{array}$ & NG \\
\hline 9. & $\begin{array}{l}36 \\
/ \mathrm{M}\end{array}$ & $\begin{array}{l}\text { Fungal } \\
\text { Keratitis }\end{array}$ & $4 \times 4.5$ & $\begin{array}{l}\text { Fusarium } \\
\text { spp. }\end{array}$ & $\begin{array}{l}\text { Scra } \\
\text { pe }\end{array}$ & $\begin{array}{l}\text { Resolved } \\
\text { keratitis } \\
\text { /ND }\end{array}$ & NA & NA & NA \\
\hline 10. & $\begin{array}{l}69 \\
/ \mathrm{M}\end{array}$ & $\begin{array}{l}\text { Perforated } \\
\text { Corneal } \\
\text { ulcer with } \\
\text { hypopyon }\end{array}$ & TCI & $\begin{array}{l}\text { Lasiodiplo } \\
\text { dia spp. }\end{array}$ & $\begin{array}{l}\text { Scra } \\
\text { pe }\end{array}$ & $\begin{array}{l}\text { Failed to } \\
\text { resolve/ } \\
\text { Y }\end{array}$ & $18 d$ & $\begin{array}{l}\text { Fungal corneal } \\
\text { ulcer }\end{array}$ & NG \\
\hline 11. & $\begin{array}{l}27 \\
/ \mathrm{F}\end{array}$ & $\begin{array}{l}\text { Microbial } \\
\text { Keratitis }\end{array}$ & $3.5 \times 2$ & $\begin{array}{l}\text { Fusarium } \\
\text { spp. }\end{array}$ & $\operatorname{Imp}$ & LFU & NA & NA & NA \\
\hline 12. & $\begin{array}{l}31 \\
/ \mathrm{M}\end{array}$ & $\begin{array}{l}\text { Corneal } \\
\text { ulcer with } \\
\text { hypopyon }\end{array}$ & TCI & $\begin{array}{l}\text { Aspergillus } \\
\text { spp. }\end{array}$ & $\operatorname{Imp}$ & $\begin{array}{l}\text { Resolved } \\
\text { keratitis/ } \\
\text { Y }\end{array}$ & $6 \mathrm{~m}$ & Corneal scar & NG \\
\hline 13. & $\begin{array}{l}75 \\
/ \mathrm{M}\end{array}$ & $\begin{array}{l}\text { Fungal } \\
\text { Keratitis }\end{array}$ & $5 \times 2$ & $\begin{array}{l}\text { Acremoniu } \\
\text { m spp. }\end{array}$ & $\mathrm{CB}$ & $\begin{array}{l}\text { Failed to } \\
\text { resolve/ } \\
\mathrm{Y}\end{array}$ & $30 d$ & $\begin{array}{l}\text { Fungal Corneal } \\
\text { ulcer }\end{array}$ & NG \\
\hline 14. & $\begin{array}{l}39 \\
/ \mathrm{M}\end{array}$ & $\begin{array}{l}\text { Microbial } \\
\text { Keratitis }\end{array}$ & 5.5 & $\begin{array}{l}\text { Fusarium } \\
\text { spp. }\end{array}$ & $\mathrm{CB}$ & $\begin{array}{l}\text { Failed to } \\
\text { resolve/ } \\
\text { Y }\end{array}$ & $28 d$ & $\begin{array}{l}\text { Fungal Corneal } \\
\text { ulcer }\end{array}$ & $\mathrm{Y}$ \\
\hline 15. & $\begin{array}{l}44 \\
/ \mathrm{M}\end{array}$ & $\begin{array}{l}\text { Perforated } \\
\text { corneal }\end{array}$ & TCI & ND & $\mathrm{CB}$ & $\begin{array}{l}\text { Perforate } \\
\text { d corneal }\end{array}$ & Od & $\begin{array}{l}\text { Fungal Corneal } \\
\text { ulcer }\end{array}$ & $\mathrm{Y}$ \\
\hline
\end{tabular}




\begin{tabular}{|c|c|c|c|c|c|c|c|c|c|}
\hline & & ulcer & & & & ulcer/Y & & & \\
\hline 16. & $\begin{array}{l}59 \\
/ \mathrm{M}\end{array}$ & $\begin{array}{l}\text { Fungal } \\
\text { Keratitis }\end{array}$ & TCI & $\begin{array}{l}\text { Fusarium } \\
\text { spp. }\end{array}$ & $\mathrm{CB}$ & $\begin{array}{l}\text { Large } \\
\text { corneal } \\
\text { ulcer/Y }\end{array}$ & $1 d$ & $\begin{array}{l}\text { Fungal Corneal } \\
\text { ulcer }\end{array}$ & Y \\
\hline 17. & $\begin{array}{l}48 \\
/ \mathrm{M}\end{array}$ & $\begin{array}{l}\text { Microbial } \\
\text { Keratitis }\end{array}$ & $3 \times 4$ & $\begin{array}{l}\text { Aspergillus } \\
\text { spp. }\end{array}$ & $\mathrm{CB}$ & $\begin{array}{l}\text { Large } \\
\text { corneal } \\
\text { ulcer/Y }\end{array}$ & $6 \mathrm{~d}$ & $\begin{array}{l}\text { Fungal Corneal } \\
\text { ulcer }\end{array}$ & NG \\
\hline 18. & $\begin{array}{l}46 \\
/ \mathrm{M}\end{array}$ & $\begin{array}{l}\text { Microbial } \\
\text { Keratitis }\end{array}$ & $3 \times 2$ & NG & $\mathrm{CB}$ & $\begin{array}{l}\text { Large } \\
\text { corneal } \\
\text { ulcer/Y }\end{array}$ & $4 d$ & $\begin{array}{l}\text { Fungal Corneal } \\
\text { ulcer }\end{array}$ & Y \\
\hline 19. & $\begin{array}{l}54 \\
/ \mathrm{M}\end{array}$ & $\begin{array}{l}\text { Fungal } \\
\text { Keratitis }\end{array}$ & $6 \times 5$ & $\begin{array}{l}\text { Aspergillus } \\
\text { spp. }\end{array}$ & $\mathrm{CB}$ & $\begin{array}{l}\text { Large } \\
\text { corneal } \\
\text { ulcer/Y }\end{array}$ & $4 d$ & $\begin{array}{l}\text { Fungal Corneal } \\
\text { ulcer }\end{array}$ & $\mathrm{Y}$ \\
\hline 20. & $\begin{array}{l}58 \\
/ \mathrm{F}\end{array}$ & $\begin{array}{l}\text { Microbial } \\
\text { Keratitis }\end{array}$ & $3.5 \times 3$ & $\begin{array}{l}\text { Unid. } \\
\text { Dematiace } \\
\text { ous } \\
\text { Fungus }\end{array}$ & $\mathrm{CB}$ & $\begin{array}{l}\text { Impendin } \\
\mathrm{g} \\
\text { perforati } \\
\text { on } \\
\text { / Y }\end{array}$ & $2 d$ & $\begin{array}{l}\text { Fungal Corneal } \\
\text { ulcer }\end{array}$ & Y \\
\hline 21. & $\begin{array}{l}56 \\
/ \mathrm{M}\end{array}$ & $\begin{array}{l}\text { Fungal } \\
\text { Keratitis }\end{array}$ & $10 x 8$ & $\begin{array}{l}\text { Fusarium } \\
\text { spp. }\end{array}$ & $\mathrm{CB}$ & $\begin{array}{l}\text { Near } \\
\text { total } \\
\text { infiltrate/ } \\
\text { Y }\end{array}$ & $9 d$ & $\begin{array}{l}\text { Fungal Corneal } \\
\text { ulcer }\end{array}$ & NG \\
\hline 22. & $\begin{array}{l}44 \\
/ F\end{array}$ & $\begin{array}{l}\text { Microbial } \\
\text { Keratitis }\end{array}$ & $7 x 6$ & NG & $\mathrm{CB}$ & $\begin{array}{l}\text { No } \\
\text { response/ } \\
\text { Y }\end{array}$ & $5 d$ & $\begin{array}{l}\text { Fungal Corneal } \\
\text { ulcer }\end{array}$ & NG \\
\hline 23. & $\begin{array}{l}44 \\
/ \mathrm{M}\end{array}$ & $\begin{array}{l}\text { Perforated } \\
\text { corneal } \\
\text { ulcer }\end{array}$ & TCI & ND & $\mathrm{CB}$ & $\begin{array}{l}\text { Perforate } \\
\text { d corneal } \\
\text { ulcer/Y }\end{array}$ & Od & $\begin{array}{l}\text { Fungal Corneal } \\
\text { ulcer }\end{array}$ & $\mathrm{Y}$ \\
\hline 24. & $\begin{array}{l}37 \\
/ \mathrm{F}\end{array}$ & $\begin{array}{l}\text { Fungal } \\
\text { Keratitis }\end{array}$ & $3.5 \times 2.5$ & $\begin{array}{l}\text { Fusarium } \\
\text { spp. }\end{array}$ & $\mathrm{CB}$ & $\begin{array}{l}\text { Resolved } \\
\text { keratitis/ } \\
\text { Y }\end{array}$ & $7 \mathrm{~m}$ & Corneal scar & NG \\
\hline 25. & $\begin{array}{l}52 \\
/ \mathrm{M}\end{array}$ & $\begin{array}{l}\text { Fungal } \\
\text { Keratitis }\end{array}$ & TCI & $\begin{array}{l}\text { Burkholder } \\
\text { ia spp. }\end{array}$ & $\mathrm{CB}$ & $\begin{array}{l}\text { Resolved } \\
\text { keratitis/ } \\
\text { Y }\end{array}$ & $10 \mathrm{~m}$ & Corneal scar & NG \\
\hline 26. & $\begin{array}{l}26 \\
/ \mathrm{M}\end{array}$ & $\begin{array}{l}\text { Microbial } \\
\text { keratitis }\end{array}$ & $8 \times 5$ & $\begin{array}{l}\text { pseudo } \\
\text { allescheria } \\
\text { boydii }\end{array}$ & $\mathrm{CB}$ & $\begin{array}{l}\text { Resolved } \\
\text { keratitis/ } \\
\text { Y }\end{array}$ & $10 \mathrm{~m}$ & Corneal scar & NG \\
\hline
\end{tabular}

Abbreviations: Inf- infiltrate; M/F- male/female; CB-corneal button; Y-yes; Pres to Ker- duration between the date of first presentation and date of keratoplasty; $\mathrm{d} / \mathrm{m} / \mathrm{yrs}$-days/months/years; TCI- total corneal infiltrate; NG-no growth; NA- not applicable; ND-not done; unid: unidentified; LFU-lost to follow up; Scr-C/S: Growth of fungus in culture from scraping samples; CB-C/S: Growth of fungus in culture from corneal button samples, Imp-Impression cytology. 